\title{
Arahan Pengembangan Kawasan Wisata Pantai Nepa Berdasarkan Preferensi Pengunjung Kecamatan Banyuates Kabupaten Sampang
}

\author{
Tadaki Santoso Hasegawa dan Ema Umilia \\ Jurusan Perencanaan Wilayah dan Kota, Fakultas Teknik Sipil dan Perencanaan, \\ Institut Teknologi Sepuluh Nopember (ITS) \\ Jl. Arief Rahman Hakim, Surabaya 60111 Indonesia \\ e-mail: tadaki.santoso.hasegawa@gmail.com
}

\begin{abstract}
Abstrak-Kecamatan Banyuates, Kabupaten Sampang, memiliki kawasan wisata pantai Nepa, yang terdiri dari 6 potensi wisata di 3 desa, yakni wisata alam pantai Nepa, wisata alam hutan kera Nepa, makam petilasan Raden Segoro, wisata arung laut, wisata budaya Rokat Tase', dan wisata buatan waduk Nipah, di Desa Batioh, Desa Nepa, dan Desa Montor.

Penelitian deskriptif ini menggunakan analisis deskriptif, yang digunakan untuk mencapai sasaran pertama analisis potensi wisata, sasaran kedua analisis preferensi pengunjung, hingga sasaran terakhir merumuskan arahan pengembangan kawasan wisata pantai Nepa berdasarkan preferensi pengunjung.

Rumusan arahan pengembangan kawasan tersebut menghasilkan arahan pengembangan berupa penyediaan, perbaikan, pemeliharaan, dan peningkatan akses prasarana dan sarana pariwisata, peningkatan kesadaran terhadap kelestarian lingkungan dan sikap masyarakat terhadap pengunjung dengan nilai-nilai sapta pesona, penambahan jenis atraksi wisata, penyediaan akomodasi, peningkatan partisipasi masyarakat, dan promosi kawasan, untuk setiap potensi wisata.
\end{abstract}

Kata Kunci-arahan pengembangan, kawasan pantai Nepa, potensi wisata, Preferensi pengunjung.

\section{PENDAHULUAN}

$\mathrm{P}$ ARIWISATA adalah suatu perjalanan yang dilakukan untuk sementara waktu dari suatu tempat ke tempat lain, dengan maksud bukan untuk berusaha (business) atau untuk mencari nafkah di tempat yang dikunjungi, tetapi semata-mata untuk menikmati perjalanan tersebut guna pertamasyaan dan rekreasi atau memenuhi keinginan yang beraneka ragam (Yoeti, 1996). Pariwisata adalah suatu aktivitas manusia yang dilakukan secara sadar, yang mendapat pelayanan secara bergantian di antara orang-orang dalam suatu negara itu sendiri, meliputi tempat tinggal orang-orang daerah lain untuk sementara waktu dalam mencari kepuasan yang beraneka ragam dan berbeda dengan apa yang dialami dimana ia memperoleh pekerjaan tetap (Wahab, dalam Yoeti 1983). Dengan demikian, pariwisata bisa diartikan sebagai perjalanan sementara manusia ke tempat lain dengan tujuan memperoleh pelayanan dalam memenuhi kebutuhan jasmani dan rohani dan keinginan lain yang beraneka ragam di suatu waktu tertentu. Permintaan wisatawan terhadap adanya kegiatan wisata atau tempat wisata selalu tinggi. Hal tersebut mengakibatkan penawaran terhadap pariwisata semakin tinggi dari waktu ke waktu.

Pariwisata adalah salah satu dari jenis industri baru yang mampu mempercepat pertumbuhan ekonomi dan penyediaan lapangan kerja, peningkatan penghasilan, standar hidup serta menstimulasi sektor-sektor produktif lainnya. Dengan kata lain, juga meningkatkan daya saing wilayah dan Pendapatan Asli Daerah (PAD) [1]. Wisata mampu meningkatkan pertumbuhan ekonomi relatif cepat dengan meningkatkan pendapatan, meningkatkan standar hidup dan menstimulasi sector- sector produktivitas lainnya (Nurisyah et al, 2003). Pariwisata juga dapat menciptakan lapangan pekerjaan dan menjadi sumber pendapatan bagi penduduk lokal dan menarik investor dari daerah luar (Rosyidie, 2000). Selain itu pajak dan retribusi dari tempat wisata merupakan sumber pendapatan bagi daerah tempat wisata tersebut.

Kabupaten Sampang memiliki berbagai tujuan/destinasi wisata. Tujuan wisata, yang utama, yang terdapat di Kabupaten Sampang salah satunya adalah pantai Nepa. Kawasan wisata pantai Nepa terletak di Kecamatan Banyuates, Kabupaten Sampang. Pantai Nepa terletak di bagian Utara Kabupaten Sampang, terdiri dari wisata kera Nepa, pantai Nepa, wisata sungai Nepa, waduk Nepa, aktivitas Berlayar, Wisata Budaya Rokat Tase', dan Makam Petilasan Raden Segoro. Jarak pantai Nepa dari jalan arteri primer sejauh 300 meter dan berjarak kurang lebih $60 \mathrm{~km}$ dari pusat pemerintahan Kabupaten Sampang [2]

Kecamatan Banyuates sendiri memiliki luasan sebesar 141,23 km2. Sebagai kecamatan pesisir. Kecamatan Banyuates memiliki jumlah penduduk sebesar 73.625 jiwa, dengan kepadatan penduduk 521 jiwa/km2 [3]. Sejumlah wisatawan domestik telah berkunjung ke pantai Nepa. Hal ini didukung dengan perkembangan wisatawan nusantara (wisnus) yang berkunjung ke wisata kera Nepa yang tercatat pada tahun 2014 sebesar 208 orang [4].

Kondisi sarana dan prasarana pantai Nepa masih belum memadai. Hal ini ditunjukkan dengan akses jalan menuju kawasan pantai sudah rusak, meskipun sudah terjadi perkerasan. Dilain sisi, pantai Nepa masih belum seluruhnya didukung dengan utilitas, seperti air bersih, jaringan telepon, dan jaringan listrik. Masyarakat memperoleh air bersih masih dengan menadah air hujan melalui tandon-tandon terbuka milik masyarakat. Meskipun jaringan telepon belum masuk ke dalam 


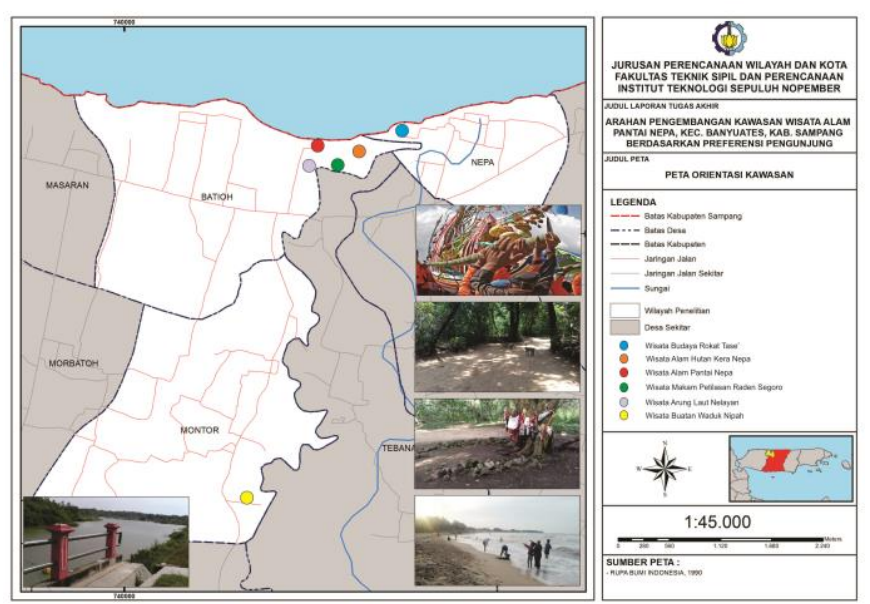

Gambar. 1. Peta Sebaran Potensi Wisata di Kawasan Wisata Pantai Nepa ditahun 2017

kawasan tersebut, namun sudah terdapat coverage jaringan telepon seluler [2].

Pada saat ini, kegiatan pariwisata di kawasan pantai Nepa telah menurun, dengan pertumbuhan jumlah pengunjung yang lambat [4]. Hal ini disebabkan oleh tidak adanya pengelolaan yang baik di kawasan pantai, yang disebabkan oleh masyarakat sendiri yang pasif dalam keikutsertaan pengembangan kawasan pariwisata sedangkan mereka sendiri menginkan andil dalam pelaksanaan pembangunan kawasan wisata Pantai Nepa tersebut (Kabag Sarpras Disbudparpora, 2016).

Pengunjung (visitor) mengeluhkan kurangnya pengembangan di kawasan wisata pantai Nepa. Pengunjung berpendapat bahwa keindahan alamnya tidak didukung dengan kebersihan lingkungan yang baik dengan masih banyaknya sampah berserakan, tidak tersedianya tempat sampah yang cukup, dan tidak ada papan peringatan untuk tidak membuang sampah sembarangan. Fasilitas yang telah ada masih kurang memadai karena fasilitas seperti toilet, kamar mandi, masjid, rumah makan, kios cinderamata, dan area bermain anak-anak tidak tersedia. Meskipun telah tersedia fasilitas, sebagai bentuk inisiasi pengembangan kawasan wisata yang dilakukan oleh pemerintah, namun tidak ada maintenance terhadap fasilitas kamar mandi yang telah rusak, bangunan joglo yang terdapat di dalam hutan kera Nepa, dan toilet (Wawancara pengunjung, 2016).

Dengan melihat kondisi fisik dan sarana dan prasarana Pantai Nepa yang buruk dan pengelolaan kawasan wisata alam pantai Nepa yang kurang baik, maka perlu disusun arahan pengembangan wisata pantai Nepa berdasarkan preferensi pengunjung Kecamatan Banyuates, Kabupaten Sampang.

\section{METODE PENELITIAN}

\section{A. Jenis dan Pendekatan Penelitian}

Dalam mencapai suatu tujuan pendekatan penelitian ini yaitu perumusan arahan pengembangan kawasan wisata berdasarkan preferensi pengunjung dilakukan dengan pendekatan secara rasionalistik. Sedangkan jenis penelitian dalam penelitian ini adalah penelitian desktriptif.

\section{B. Variabel Penelitian}

Variabel penelitian yang digunakan untuk merumuskan arahan pengembangan kawasan wisata pantai Nepa berdasarkan preferensi pengunjung adalah variabel jenis keunikan wisata, kesadaran masyarakat dalam menjaga kelestarian lingkungan, jenis kegiatan perbaikan lingkungan, jenis sarana transportasi menuju obyek wisata, kondisi jalan, ketersediaan tempat menginap, ketersediaan air bersih, ketersediaan fasilitas penunjang dan pendukung, ketersediaan pelayanan listrik, ketersedaan telekomunikasi, jenis kegiatan masyarakat pesisir, dan sikap masyarakat kepada pengunjung.

\section{Menganalisis Potensi Wisata di Kawasan Wisata Pantai Nepa}

Dilakukan analisis deskriptif kualitatif dengan melihat kondisi eksisting terkait lokasi wisata menurut variabel penelitian. Adapun hasil analisis ini adalah potensi bentuk pengembangan wisata yang terdapat di kawasan wisata pantai Nepa dari hasil perbandingan pengamatan empirik, yang di dapat dari observasi dan wawancara, terhadap penelitian dengan wisata sejenis di lokasi penelitian lain.

\section{Menganalisis Preferensi Pengunjung Mengenai Bentuk Pengembangan Kawasan Wisata Pantai Nepa}

Melalui pertanyaan-pertanyaan tertulis dalam questionnaire dan wawancara berdasarkan faktor-faktor relevan dalam pengembangan kawasan wisata alam pantai Nepa, dilakukan analisis deskriptif dengan mendeskripsikan atau menggambarkan data yang telah terkumpul mengenai bentuk pengembangan kawasan wisata berdasarkan preferensi pengunjung. Penggalian informasi mengenai kebutuhan pengunjung juga dilakukan sebagai input dalam bentuk pengembangan kawasan wisata pantai tersebut.

\section{E. Merumuskan Arahan Pengembangan Kawasan Wisata Pantai Nepa Berdasarkan Preferensi Pengunjung}

Dalam merumuskan arahan, analisis deskriptif kualitatif digunakan dalam mengkolaborasikan hasil analisis potensi wisata dan pengembangan empirik peneliti terhadap kondisi eksisting dan preferensi pengunjung mengenai bentuk pengembangan kawasan wisata pantai Nepa, berdasarkan variabel-variabel penelitian untuk setiap potensi wisata yang ada di kawasan tersebut. Analisis tersebut dilakukan dengan cara mensintesakan kedua bagian tersebut sehingga nantinya akan diperoleh arahan pengembangan kawasan wisata pantai Nepa berdasarkan preferensi pengunjung berdasarkan variabelvariabel penelitian untuk setiap potensi wisata yang ada di kawasan tersebut.

\section{HASIL DAN DISKUSI}

\section{A. Menganalisis Potensi Wisata di Kawasan Wisata Pantai Nepa}

Berdasarkan hasil analisis didapatkan informasi mengenai potensi pengembangan di kawasan wisata pantai Nepa menurut 
variabel penelitian untuk setiap potensi wisata, diantaranya :

a. Jenis Keunikan Wisata

Berpotensi dilakukan penambahan atraksi berupa kegiatan makan dipantai, berperahu, dan memancing di pantai Nepa, kegiatan kompetisi permainan, pertunjukan musik, dan kegiatan budaya lain yang sesuai dengan kebudayaan masyarakat setempat dalam kegiatan wisata budaya Rokat Tase', pemeliharaan atraksi dalam wisata Arung Laut, kegiatan memancing, kegiatan beristirahat, berbelanja, piknik, bermain, bersepeda, dan olahraga di waduk Nipah, kegiatan susur hutan/jungle track, kegiatan beristirahat, kegiatan, piknik, bermain, kegiatan penanaman bibit bakau oleh pengunjung, dan kegiatan pembelajaran alam terkait flora dan fauna di wisata Hutan Kera Nepa, dan kegiatan kegiatan pembelajaran sejarah mengenai Makam Petilasan Raden Segoro.

b. Kesadaran Masyarakat Dalam Menjaga Kelestarian Lingkungan dan Sikap Masyarakat Kepada Pengunjung.

Berpotensi dilakukan peningkatan kesadaran wisata masyarakat melalui turun tangan pemerintah dalam memberikan bimbingan dan pemahaman kepada masyarakat mengenai Sapta Pesona. Kemudian dibentuk kelompok bimbingan sehingga masyarakat, secara berlanjut, dapat mempertahankan pemahaman mereka sendiri dan mampu meningkatkan kesadaran berwisata diri masyarakat sendiri mengenai sapta pesona. Sapta pesona sendiri adalah nilai-nilai yang harus diciptakan bagi pengunjung dan masyarakat setempat di lokasi wisata

c. Jenis Sarana Transportasi dan Kondisi Jalan Menuju Obyek Wisata

Berpotensi dilakukan pembangunan jalan masuk yang menghubungkan 5 lokasi wisata dengan perkerasan jalan berupa aspal, perbaikan dan pemeliharan jalan menuju wisata Waduk Nipah, pembangunan penerangan jalan, dan penyediaan sarana transportasi menuju lokasi wisata.

d. Ketersediaan Tempat Menginap

Berpotensi dilakukan penyediaan alternatif tempat menginap pengunjung berupa tempat tinggal masyarakat setempat dan merencanakan konsep homestay sebagai konsep pengembangan tempat menginap pengunjung dan perencanaan konsep bangunan yang dapat mengkonservasi hutan seperti konsep bangunan bergaya arsitektural Neo-Vernakular di sisi sungai.

e. Ketersediaan Air Bersih, Pelayanan Listrik, Dan Telekomunikasi.

Berpotensi dilakukan pembangunan jaringan air bersih dan listrik, penyediaan akses air bersih dan kelistrikan melalui pembangunan toilet, kamar mandi, keran air, lokasi pengisian daya barang-barang elektronik pegunjung, dan fasilitas peribadatan, pemeliharaan akses telekomunikasi dengan memelihara bangunan telekomunikasi seperti BTS, dan penyediaan hotspot di beberapa lokasi pengunjung berkumpul.

f. Jenis Kegiatan Masyarakat Pesisir

Berpotensi dilakukan pembentukan satuan petugas kebersihan dan keamanan, pembentukan kelompok masyarakat untuk meningkatkan kemampuan masyarakat dalam mengelola kawasan, meningkatkan taraf pendidikan, ekonomi, dan keahlian, pelibatan masyarakat dalam pemeliharaan benda cagar budaya makam petilasan Raden Segoro, pelibatan masyarakat dalam meningkatkan pengusaha pariwisata seperti penjual makanan dan minuman, souvenir, dan oleh-oleh, fotografer, guide tour, penyedia tiket cepat, dan petugas parkir.

g. Fasilitas Penunjang dan Pendukung Pariwisata

Berpotensi dilakukan penyediaan fasilitas seperti MCK, rumah makan, kios cinderama, masjid, papan infromasi sejarah, ajakan menjaga kebersihan, dan penunjuk jalan, loket masuk, petugas kebersihan dan keamanan, serta pemeliharaan fasilitas yang sudah ada.

h. Jenis Kegiatan Perbaikan Lingkungan

Berpotensi dilakukan penyediaan pengelola kebersihan oleh masyarakat dalam hal pembentukan petugas kebersihan, pengelolaan sampah, pembuangan limbah cari, daur ulang sampah, pengadaan air bersih, dan evaluasi lingkungan, penyediaan pengelola benda cagar budaya oleh masyarakat, dan pemugaran benda cagar budaya.

\section{B. Menganalisis Preferensi Pengunjung Mengenai Bentuk Pengembangan Kawasan Wisata Pantai Nepa}

Dari keseluruhan pertanyaan yang terjawab sebagai masukan yang diperoleh dari penyebaran questionnaire kepada pengunjung mengenai pengembangan kawasan wisata pantai Nepa dan upaya penggalian informasi lain melalui wawancara, diperoleh informasi mengenai karakteristik wisatawan, preferensi pengunjung menurut variabel-variabel penelitian, bentuk-bentuk pengembangan kawasan wisata menurut pengunjung,

Menurut preferensi pengunjung, yang dibutuhkan dalam mengembangkan kawasan wisata pantai Nepa adalah :

a. Jenis Keunikan Wisata

Diperlukan penambahan papan informasi mengenai berbagai potensi wisata yang terdapat di kawasan wisata, pemeliharaan keaslian potensi wisata yang ada, dan meningkatkan kegiatan/atraksi yang dapat dilakukan oleh pengunjung dengan disediakannya fasilitas taman bermain untuk anak-anak dan rumah makan.

b. Kesadaran Masyarakat Dalam Menjaga Kelestarian Lingkungan

Diperlukan peningkatan kesadaran masyarakat setempat dan pengunjung yang masih membuang sampah sembarangan, meningkatkan kemauan masyarakat dalam menjaga kebersihan dengan dilakukan pembimbingan mengenai Sapta Pesona, dan menyediakan fasilitas 
kebersihan seperti tempat sampah dan papan ajakan menjaga kebersihan untuk membiasakan masyarakat dalam menjaga kebersihan lingkungan.

c. Sikap Masyarakat Kepada Pengunjung

Pengunjung menginginkan peningkatan kesadaran wisata masyarakat berdasarkan nilai-nilai Sapta Pesona, dimana masyarakat dapat memuculkan rasa aman dan tenang bagi pengunjung. Pengunjung menginginkan perbaikan sikap tukang parkir yang menghalau pengunjung dalam memilih lokasi parkir yang disediakan di masing-masing halaman rumah milik masyarakat setempat dengan lebih ramah dalam menerima pengunjung.

d. Jenis Sarana Transportasi dan Kondisi Jalan Menuju Obyek Wisata

Berdasarkan preferensi pengunjung, diperlukan perbaikan dan pelebaran jalan terhadap jalan masuk menuju jalan penghubung 5 lokasi wisata di Utara kawasan wisata pantai Nepa, pembangunan drainase disisi jalan masuk lokasi wisata yang berada di tengah sawah untuk mengatasi becek dan banjir saat musim penghujan, dan perbaikan dan perluasan tempat parkir serta membangun manajemen tempat parkir yang baik.

e. Ketersediaan Tempat Menginap

Pengunjung menunjukkan ketertarikan untuk menginap di rumah penduduk setempat. Meskipun tidak terdapat pengunjung yang menginap, namun mereka berharap apabila mereka harus menginap dalam berkunjung, maka mereka memilih rumah penduduk setempat dalam memenuhi kebutuhan akomodasi mereka.

f. Ketersediaan Air Bersih, Pelayanan Listrik, Dan Telekomunikasi.

Berdasarkan preferensi pengunjung, diketahui bahwa secara umum pengunjung berpendapat bahwa diperlukan peningkatan penyediaan akses terhadap air bersih dan listrik dengan membangun fasilitas toilet, keran air, kamar mandi, dan fasilitas peribadatan. peningkatan akses terhadap listrik dengan disediakan lokasi pengisian daya barang-barang elektronik kebutuhan pengunjung, penyediaan penerangan jalan, dan pemeliharaan jaringan telekomunikasi.

g. Jenis Kegiatan Masyarakat Pesisir

Berdasarkan preferensi pengunjung, bentuk pengembangan yang perlu dilakukan adalah peningkatan partisipasi masyarakat dalam menjaga kondisi lingkungan dan meningkatkan kenyamanan dalam berwisata, penyediaan tempat sampah oleh masyarakat, pelibatan masyarakat dalam menciptakan atraksi berbeda, penyediaan petugas parkir, dan penyediaan petugas keamanan.

h. Fasilitas Penunjang dan Pendukung Pariwisata

Berdasarkan preferensi pengunjung, kebutuhan fasilitas yang dibutuhkan paling utama adalah kebutuhan fasilitas peribadatan, khususnya masjid, fasilitas pendukung pariwisata yang diperlukan adalah fasilitas toilet, tempat parkir yang baik, kios cinderamata, papan informasi, rumah makan, taman bermain, dan fasilitas kebersihan seperti tempat sampah, untuk meningkatkan kenyamanan dan ketenangan pengunjung dalam menikmati wisata.

i. Jenis Kegiatan Perbaikan Lingkungan

Berdasarkan preferensi pengunjung, tindakan yang paling utama perlu dilakukan adalah penyediaan fasilitas lingkungan pariwisata. Selain itu, pengunjung juga membutuhkan tindakan perbaikan berupa pencerdasan pengunjung dalam melestarikan lingkungan pariwisata, pelaksanaan pembersihan sampah yang rutin, perawatan fasilitas wisata, dan penambahan papan peringatan menjaga kebersihan.

\section{Merumuskan Arahan Pengembangan Kawasan Wisata}

Pantai Nepa Berdasarkan Preferensi Pengunjung

Arahan pengembangan kawasan wisata pantai Nepa berdasarkan preferensi pengunjung adalah :

a. Pengembangan Utilitas Berupa Jaringan Air Bersih, Listrik, Dan Telekomunikasi.

Penyediaan, peningkatan kemudahan akses, peningkatan pemanfaatan, dan pemeliharaan jaringan listrik; penyediaan dan peningkatan kemudahan akses jaringan air bersih; dan peningkatan kemudahan akses dan pemeliharaan jaringan telekomunikasi.

b. Pengembangan fasilitas penunjang dan pendukung pariwisata

Membangun dan memelihara fasilitas peribadatan; menyediakan, menambah, dan menjaga kondisi fasilitas kebersihan; menyediakan dan memelihara satuan petugas keamanan di setiap lokasi wisata; memperbaiki dan memelihara kondisi perahu nelayan di lokasi wisata arung laut; memperbaiki dan memelihara kondisi perahu nelayan di lokasi wisata arung laut; membangun dan memelihara loket masuk wisata di setiap lokasi wisata; membangun dan memelihara fasilitas pertandaan (signage), meliputi papan informasi lokasi wisata, papan informasi sejarah lokasi wisata, papan penunjuk jalan, papan informasi ajakan menjaga kelestarian lingkungan, dan rambu-rambu jalan/lalu lintas di dalam dan sekitar lokasi wisata; membangun kios cinderamata dan rumah makan; membangun dan memelihara tempat parkirdengan perkerasan non-aspal di kawasan wisata pantai Nepa; membangun pos jaga di tempat parkir; dan menyediakan berbagai fasilitas lainnya seperti taman bermain untuk anak-anak, lapangan voli pantai, rumah makan, bungalow, penyediaan spot-spot terbaik fotografi, dan penyediaan pelampung untuk kegiatan berrenang.

c. Pengembangan keunikan wisata/daya tarik wisata di setiap lokasi wisata di kawasan wisata pantai Nepa.

Pengembangan dilakukan dengan meningkatkan jumlah atraksi wisata di lokasi-lokasi wisata di kawasan wisata pantai Nepa, seperti makan dipantai, berperahu, memancing, kegiatan kompetisi permainan, pertunjukan 
musik, budaya masyarakat setempat, kegiatan beristirahat, berbelanja, piknik, bermain, bersepeda, olahraga, susur hutan/jungle track, kegiatan beristirahat, kegiatan penanaman bibit bakau oleh pengunjung, dan kegiatan pembelajaran alam terkait flora dan fauna, dan pengenalan sejarah terbentuknya hutan kera Nepa berdasarkan legenda Raden Segoro, serta memelihara tersedianya kegiatan atraksi/kegiatan yang telah ada pada wisata Arung Laut (perahu nelayan).

d. Pengembangan Akomodasi Di Kawasan Wisata Pantai Nepa.

Menyediakan alternatif akomodasi berupa tempat tinggal masyarakat setempat yang dapat digunakan untuk melayani pengunjung yang menginap dalam menimati wisata pantai Nepa, wisata budaya Rokat Tase', wisata arung laut, dan wisata waduk Nipah.

Merencanakan akomodasi alternatif berupa tempat tinggal masyarakat setempat dengan konsep homestay sebagai bentuk pengembangan akomodasi ke depan untuk menjaga interaksi masyarakat setempat terhadap pengunjung dan alam.

Merencanakan pembangunan resort /akomodasi yang dapat mengkonservasi hutan dengan konsep bangunan arsitektural modern Neo-Vernakular di sisi sungai dan muara di samping hutan kera Nepa.

e. Pengembangan Kesadaran Masyarakat Terhadap Kelestarian Lingkungan Pesisir Dan Sikap Masyarakat Terhadap Pengunjung

Membimbing dan memahamkan masyarakat mengenai Sapta Pesona difasilitasi oleh pemerintah untuk meningkatkan daya tarik pengunjung. Secara bertahap proses pembimbingan dilakukan dan pada akhirnya masyarakat dapat memahami dan mampu memberikan bimbingan dan pemahaman kepada masyarakat sendiri secara mandiri dalam meningkatkan kesadaran masyarakat dalam menjaga kelestarian pesisir dan sikap masyarakat terhadap pengunjung.

f. Pengembangan Aksesibilitas Di Kawasan Wisata Pantai Nepa

Meningkatkan kemudahan akses pengunjung terhadap lokasi-lokasi wisata, dengan pengembangan meliputi pembangunan, perbaikan, dan pemeliharaan kondisi jalan meliputi perkerasan jalan berupa aspal, pembangunan PJU (penerangan jalan umum), dan pelebaran jalan, khususnya untuk jalan masuk lokasi wisata yang menghubungkan 5 lokasi wisata meliputi wisata alam pantai Nepa, wisata alam hutan kera Nepa, wisata alam Arung Laut, wisata budaya makam petilasan Raden Segoro, dan wisata budaya Rokat Tase'; menyediakan dan memelihara sarana transportasi umum dari jalan raya menuju lokasi-lokasi wisata di kawasan wisata pantai Nepa; memperbaiki dan memelihara kondisi jalan wisata buatan waduk Nepa ; dan Merencanakan sirkulasi kendaraan di dalam lokasi wisata waduk Nipah. g. Pengembangan Jenis Kegiatan Masyarakat Di Kawasan Wisata Pantai Nepa

Meningkatkan kemudahan akses pengunjung terhadap lokasi-lokasi wisata, dengan pengembangan meliputi pembangunan, perbaikan, dan pemeliharaan kondisi jalan meliputi perkerasan jalan berupa aspal, pembangunan PJU (penerangan jalan umum), dan pelebaran jalan, khususnya untuk jalan masuk lokasi wisata yang menghubungkan 5 lokasi wisata meliputi wisata alam pantai Nepa, wisata alam hutan kera Nepa, wisata alam Arung Laut, wisata budaya makam petilasan Raden Segoro, dan wisata budaya Rokat Tase'; menyediakan dan memelihara sarana transportasi umum dari jalan raya menuju lokasi-lokasi wisata di kawasan wisata pantai Nepa; memperbaiki dan memelihara kondisi jalan wisata buatan waduk Nepa ; dan Merencanakan sirkulasi kendaraan di dalam lokasi wisata waduk Nipah.

h. Pengembangan jenis kegiatan masyarakat di kawasan wisata pantai Nepa

Penyediaan jasa tour guide, yang menjelaskan sejarah budaya Rokat Tase', yang dilakukan oleh masyarakat setempat; pembentukan kelompok masyarakat dari warga setempat yang bertugas untuk meningkatkan kemampuan masyarakat setempat dalam melestarikan budaya setempat, meningkatkan taraf pendidikan masyarakat setempat, pembentukan dan perolehan pekerjaan, dan meningkatkan kemampuan serta keahlian masyarakat dalam mengelola kawasan mangrove atau hutan bakau di hutan kera Nepa dan makam petilasan Raden Segoro dengan difasilitasi oleh pemerintah; dan peningkatan partisipasi masyarakat dengan melibatkan masyarakat di sekitar waduk Nipah dengan lebih baik, dengan meningkatkan penguasaha pariwisata seperti penjual makanan dan minuman khas, oleh-oleh, souvenir, jasa-jasa seperti fotografer, penyedia tiket cepat, dan menggunakan jasa masyarakat setempat menjadi petugas parkir dan petugas kebersihan.

i. Pengembangan jenis tindakan perbaikan lingkungan kawasan wisata pantai

Pengembangan jenis tindakan perbaikan lingkungan meliputi peningkatan pengelolaan kebersihan pantai Nepa, waduk Nipah, wisata Arung Laut, hutan kera Nepa, dan makam petilasan Raden Segoro dalam hal pengelolaan sampah, pembuangan limbah cair, daur ulang sampah, pengadaan air bersih, penyediaan fasilitas kebersihan, dan dilakukan evaluasi lingkungan, dengan masyarakat sebagai pelaku pengelolaan dengan tanggung jawab secara keseluruhan terhadap kebersihan dan keamanan; pencerdasan pengunjung dalam melestarikan pariwisata; pelestarian flora dan fauna dan pelestarian cagar budaya di wisata hutan kera Nepa dan makam petilasan Raden Segoro. 
j. Pengembangan pengelolaan operasional dan promosi kawasan wisata pantai Nepa berdasarkan karakteristik pengunjung di kawasan pantai Nepa

Masyarakat bersama dengan pengusaha pariwisata dan pemerintah bekerjasama dalam mengembangkan kawasan wisata dengan kegiatan pengelolaan dan promosi. Kegiatan pengelolaan operasional dan promosi yang dilakukan diantaranya membentuk paket wisata yang terdiri dari biaya berwisata perseorangan, kelompok, atau massal, dengan harga yang progresif menurun; menentukan waktu beroperasi lokasi wisata yang interaktif terhadap seluruh lokasi wisata di kawasan wisata pantai Nepa, dengan membedakan lama jam beroperasi di setiap lokasi wisata yang dapat meningkatkan jumlah kunjungan ke beberapa lokasi wisata dalam sekali kunjungan, menentukan jam beroperasi yang lebih panjang di musim liburan, hari raya ketupatan khas Madura, dan hari libur nasional; menentukan fokus penyebaran informasi/promosi terhadap lokasi calon pengunjung berusia muda dan lokasi asal calon pengunjung mayoritas mengenai kawasan wisata pantai Nepa, sehingga dapat meningkatkan pengetahuan calon pengunjung mengenai kawasan wisata pantai Nepa yang berimplikasi meningkatnya jumlah kunjungan ke kawasan tersebut dengan lebh baik.; dan mengembangkan koridor wisata menuju kawasan wisata pantai Nepa dengan diciptakannya usaha pariwisata di sekitar jalan menuju kawasan wisata, meningkatkan jumlah signage menuju kawasan wisata, dan meningkatkan estetika korridor bertemakan wisata.

\section{KESIMPULAN}

Analisis potensi wisata di kawasan wisata pantai Nepa dilakukan dengan analisis deskriptif untuk membandingkan kondisi potensi wisata terhadap penelitian lain sejenis menurut variabel-variabel penelitian dan potensi wisata yang ada sehingga dapat disimpulkan potensi pengembangan yang dapat dilakukan di kawasan tersebut. Dari hasil analisis diketahui bahwa kawasan wisata pantai Nepa berpotensi dikembangkan dengan penyediaan prasarana dan sarana penunjang dan pendukung, penambahan atraksi, perbaikan kondisi jalan, penyediaan transportasi umum, peningkatan kesadaran masyarakat terhadap lingkungan dan sikap masyarakat terhadap pengunjung, penyediaan akomodasi, dan peningkatan kesadaran masyarakat dalam pelestarian lingkungan dan sikap kepada pengunjung.

Analisis preferensi pengunjung menghasilkan keinginan pengunjung dalam hal pemenuhan komponen supply pariwisata dalam menikmati kawasan wisata pantai Nepa menurut. Analisis deskriptif dilakukan dalam menemukan informasi baru dari data-data kualitatif dan kuantitatif yang ditabulasikan menurut variabel-variabel penelitian. Hasil analisis tersebut adalah preferensi bentuk pengembangan menurut variabelvariabel penelitian.
Rumusan arahan pengembangan dilakukan dengan menggunakan analisis deskriptif dalam mengkolaborasikan hasil analisis potensi wisata terhadap preferensi pengunjung mengenai bentuk pengembangan kawasan menurut variabelvariabel penelitian. Arahan pengembangan yang terbentuk adalah pembangunan, perbaikan, peningkatan pemanfaatan, dan pemeliharaan prasarana dan sarana penunjang dan pendukung pariwisata; perbaikan dan pemeliharaan kondisi jalan; peningkatan kesadaran dan sikap masyarakat terhadap kelestarian lingkungan dan pengunjung; perencanaan bentuk akomodasi homestay dan bangunan Neo-Vernakular yang dapat mengkonservasi kawasan; melaksanakan tindakan perbaikan lingkungan berupa pembersihan dan penyediaan petugas kebersihan dan keamanan.

\section{DAFTAR PUSTAKA}

[1] Wahab, S. Ph.D. (1976). Tourism Management. PT. Pradnya Paramita : Jakarta.

[2] Dinas Kebudayaan, Pariwisata, dan Olahraga Kabupaten Sampang. 2013. Dokumen Rencana Induk Pengembangan Pariwisata (RIPPDA) Kabupaten Sampang. Sampang : Pemerintah Kabupaten Sampang.

[3] Badan Pusat Statistik Kabupaten Sampang. 2015. Kecamatan Banyuates Dalam Angka. Sampang: BPS Kab. Sampang.

[4] Dinas Pariwisata Provinsi Jawa Timur. 2014. Pariwisata Dalam Angka Provinsi Jawa Timur 2014. Jawa Timur : Dispar Jatim.

[5] Badan Perencanaan dan Pembangunan Kabupaten Sampang. 2012. Rencana Tata Ruang Wilayah Kabupaten Sampang 2012-2032. Sampang : Bappeda Kabupaten Sampang.

[6] Kementrian pariwisata. 2009. Undang-undang Kepariwisataan No.10 Tahun 2009. Kementrian Pariwisata dan Kebudayaan : Jakarta, Indonesia. 